\title{
УЛЬТРАСТРУКТУРА ТКАНИН ПАРОДОНТА НАПРИКІНЦІ ДРУГОГО ТИЖНЯ ЕКСПЕРИМЕНТАЛЬНОГО ОПІӦ̈ДНОГО ВПЛИВУ
}

Кандидат медичних наук, доцент Фік В. Б.

Кандидат медичних наук, доцент Ковалишин О. $\boldsymbol{A}$.

Кандидат медичних наук, доиент Пальтов $\boldsymbol{G}$. В.

Доктор медичних наук, професор Кривко Ю. Я.

Львівський національний медичний університет імені Данила Галиџького, кафедра нормальної анатомії, м. Львів, Україна

DOI: https://doi.org/10.31435/rsglobal_ws/31082019/6638

\section{ARTICLE INFO}

Received: 20 June 2019

Accepted: 26 August 2019

Published: 31 August 2019

\section{KEYWORDS}

periodontal tissue,

opioid exposure,

electron microscopic research, rats \begin{abstract}
The following work is aimed at the study of submicroscopic disorganization in periodontal tissues with a two-week action of an opioid analgesic in an experiment. The aim was achieved by means of ultrastructural imaging of the cellular components of the mucous membrane of the gums and links of the hemomicrocirculatory bed. Ultrastructural preparations were prepared according to the conventional method. The conducted research provide a morphological basis to trace, at a more distant date, submicroscopic changes in soft periodontal tissues in dynamics against the background of a gradually increasing dose of opioid analgesic in the experiment.
\end{abstract}

Citation: Фік В. Б., Ковалишин О. А., Пальтов С. В., Кривко Ю. Я. (2019) Ultrastruktura Tkanyn Parodonta Naprykintsi Druhoho Tyzhnia Eksperymentalnoho Opioidnoho Vplyvu. World Science. 8(48), Vol.2. doi: 10.31435/rsglobal_ws/31082019/6638

Copyright: () 2019 Фік В. Б., Ковалишин О. А., Пальтов С. В., Кривко Ю. Я. This is an open-access article distributed under the terms of the Creative Commons Attribution License (CC BY). The use, distribution or reproduction in other forums is permitted, provided the original author(s) or licensor are credited and that the original publication in this journal is cited, in accordance with accepted academic practice. No use, distribution or reproduction is permitted which does not comply with these terms.

Результати статті відповідають плану наукових досліджень Львівського національного медичного університету імені Данила Галицького іє частиною науково-дослідної теми кафедри нормальної анатомії «Структурна організація, ангіоархітектоніки та антропометричні особливості органів у внутрішньо та позаутробному періодах розвитку, за умов екзо- та ендопатогених факторів» (номер держреєстрації 0115U000041) впродовж 2015 - 2019 pp.

Вступ. За даними ВООЗ, у світі понад 80\% населення потерпає від захворювань пародонта, що призводить до втрати зубів, зниження імунного статусу, формування алергічного стану, утворення вогнищ хронічної інфекції, мікробної сенсибілізації $[1,2]$. Зв'язок пародонтита 3 різними системними розладами призвів до еволюції нової гілки, яка отримала назву "пародонтологічна медицина" [3]. Стоматологічні та пародонтологічні захворювання значно частіше проявляються у наркозалежних, ніж у загальній популяції [4 - 7]. Зважаючи на те, що проблема наркозалежності невпинно зростає, в стоматології вкрай необхідні дані про стан органів ротової порожнини, структурних компонентів пародонта при дії опіоїдних середників, як в клінічному так і морфологічному аспектах [8 - 10]. Це ствердження спонукає нас провести експериментальне дослідження у тварин на субмікроскопічному рівні, моделюючи патологічний процес в тканинах пародонта на фоні гострої дії опіоїдного аналгетика налбуфін, який би був максимально наближений до адекватних умов в людини.

Матеріали і методи досліджень. Експериментальне дослідження проведено на 15 статевозрілих щурах-самцях лінії Wistar, масою 160 г, віком 4,5 - 5 місяців. Тваринам протягом 14 діб проводили щоденно, в одному проміжку часу внутрішньом'язові ін'єкції препарату налбуфін, у 
дозі 0,212 мг/кг [11]. Контролем слугували 5 білих щурів-самців, яким проводили внутрішньом'язові ін'єкції фізіологічного розчину. Усі тварини знаходились в умовах віварію і робота, що стосувалася питань утримання, догляду, маркування та всі інші маніпуляції проводилися із дотриманням положень "Свропейської конвенції про захист хребетних тварин, які використовуються для експериментальних та інших наукових цілей” [Стразбург, 1985]. Тварин присипляли внутрішньоочеревинним введенням тіопенталу натрію (25 мг/кг) перед проведенням забору біопсійного матеріалу. Для електронно-мікроскопічного дослідження використали фрагменти м'яких тканин пародонта в ділянці ясенного краю щелеп. Ультраструктурні препарати готували за загальноприйнятою методикою [12].

Результати дослідження. Субмікроскопічно в епітеліальній пластинці вільної ії ділянки спостерігається реорганізація епітеліоцитів. У клітинах базального шару ядра включають осміофільні ділянки гетерохроматину, ядерця невеликі, компактні. Каріолема має окремі інвагінації, перинуклеарні простори місцями збільшені. У цитоплазмі таких клітин наявні пошкоджені органели. Більшість мітохондрій набряклі, мають електронносвітлий матрикс, подекуди у вигляді різних за розмірами вакуолеподібних структур. У гіалоплазмі погано контуруються тонофіламенти, частина їх гомогенізована. Плазмолеми на окремих ділянках стають нечіткими, порушуються напівдесмосомальні контакти 3 базальною мембраною. Відмічається нерівномірне збільшення міжклітинних просторів, руйнування контактів між епітеліоцитами (рис.1).

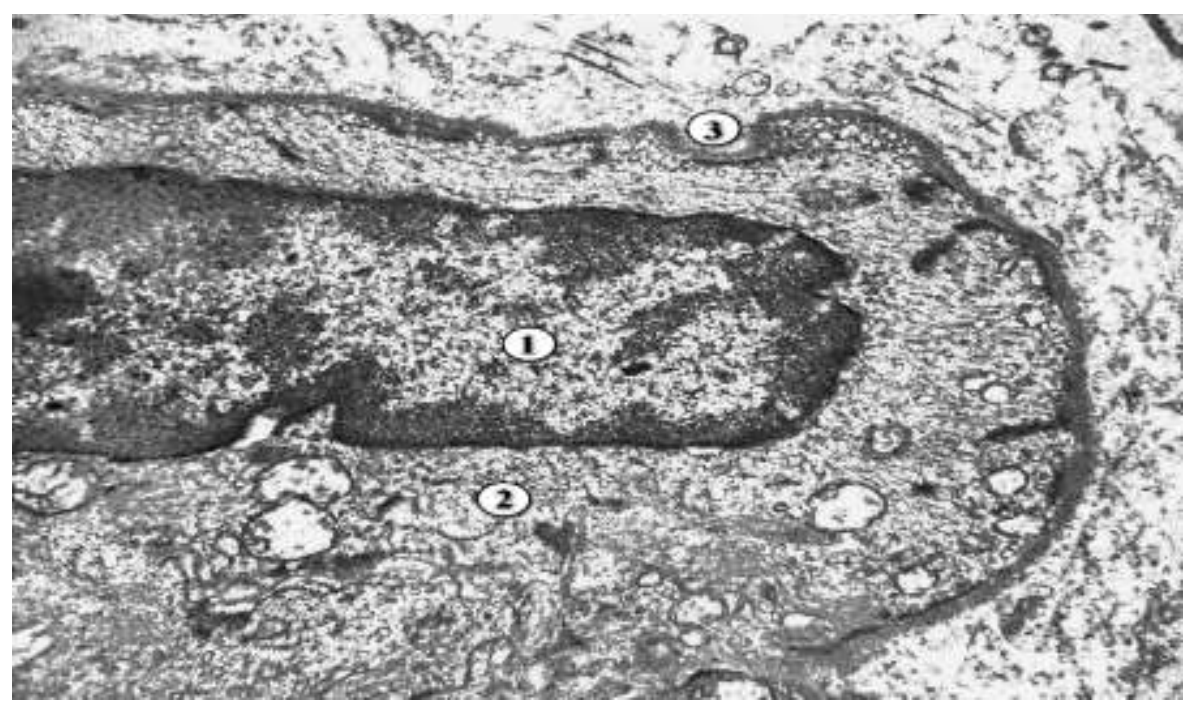

Рис. 1. Ультраструктура епітелію вільної частини ясен щура через два тижні при застосуванні опіоїу. Мікрофотографія. 3б. х12000. Ядро (1) і цитоплазма (2) епітеліоцита базального шару, базальна мембрана (3).

Епітеліоцити остистого і зернистого шарів також мають зміни структури ядра i цитоплазми. Ядра виглядають зменшеними за площею, мають інвагінації каріолеми, у каріоплазмі особливо клітин зернистого шару багато осміофільних ділянок гетерохроматину. У цитоплазмі таких епітеліоцитів наявні різних розмірів, іноді крупні грудки кератогіаліну. Порушуються десмосомальні контакти.

Субмікроскопічні дослідження епітелію ясенної борозни тварин цієї групи також виявили зміни його клітин. Відмічається набряк цитоплазми частини епітеліоцитів базального $\mathrm{i}$ шипуватого шарів, просвітлена їх цитоплазма включає пошкоджені ультраструктури. Ядра поверхневих шарів мають інвагінації каріолеми, а цитоплазма вакуолеподібні структури (рис. 2). Міжклітинні контакти нечітко контуровані, локально збільшені міжклітинні простори.

Через два тижні під впливом опіоїду субмікроскопічно встановлена реорганізація епітелію прикріпленої частини ясен тварин. Епітеліоцити мають подовгастої форми ядра 3 глибокими інвагінаціями каріолеми, гетерохроматин локалізованій біля ядерної оболонки. У цитоплазмі спостерігаються гіпертрофовані з просвітленим матриксом мітохондрії. Характерні розширені міжклітинні простори, у яких є довгі цитоплазматичні вирости (рис. 3). 


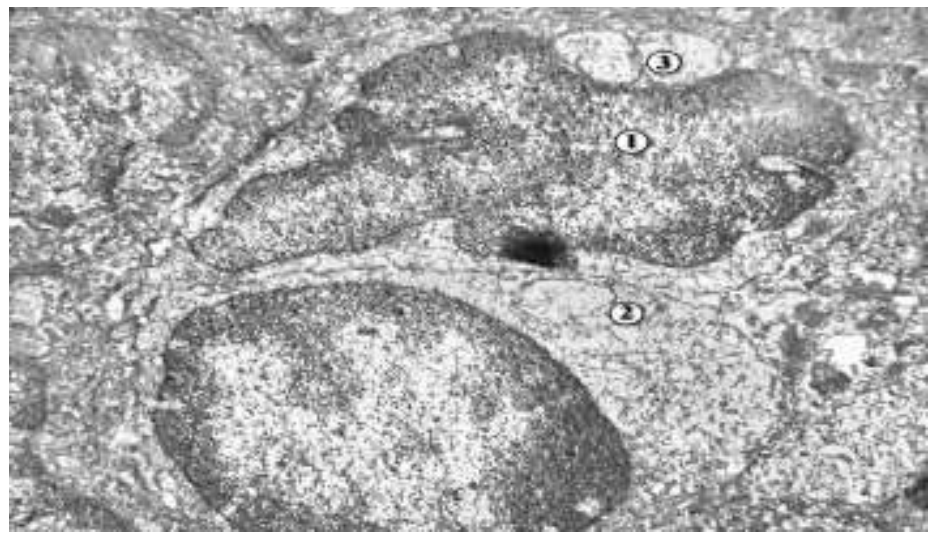

Рис. 2. Ультраструктура епітелію ясенної борозни шура через два тижні при застосуванні опіоїду. Мікрофотографія. Зб. х9000. Ядро з інвагінаџіями каріолеми (1), набрякла ділянка цчитоплазми (2), вакуолеподібні структури (3).

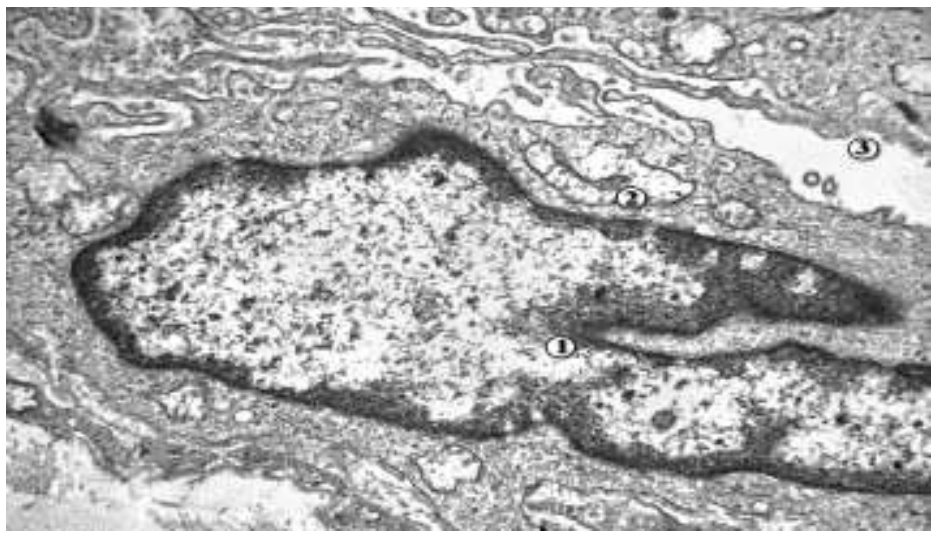

Рис. 3. Ультраструктура епітелію прикріпленої частини ясен шура через два тижні при застосуванні опіоїу. Мікрофотографія. 3б. х12000. Ядро з глибокою інвагінацією каріолеми (1), пошкоджена мітохондрія (2), розширений міжклітинний простір (3).

Проведені електронномікроскопічні дослідження періодонта тварин експериментальної групи через два тижні при застосуванні опіоїду встановили, що його структура змінюється. Колагенові волокна зберігають пучкове розташування, проте частково фрагментуються. Наявний помірний набряк аморфного компоненту міжклітинної речовини сполучної тканини. Фібробласти і фіброцити мають неправильної форми 3 інвагінаціями каріолеми ядра, в яких значну площу займає осміофільний гетерохроматин. У цитоплазмі є пошкоджені органели, розширені канальця ендоплазматичної сітки, мітохондрії з просвітленим матриксом (рис. 4, 5). В складі періодонта відмічається дегрануляція базофілів, їх гранули мають неоднакову електронну щільність, частина їх розташовані за межами плазмолеми.

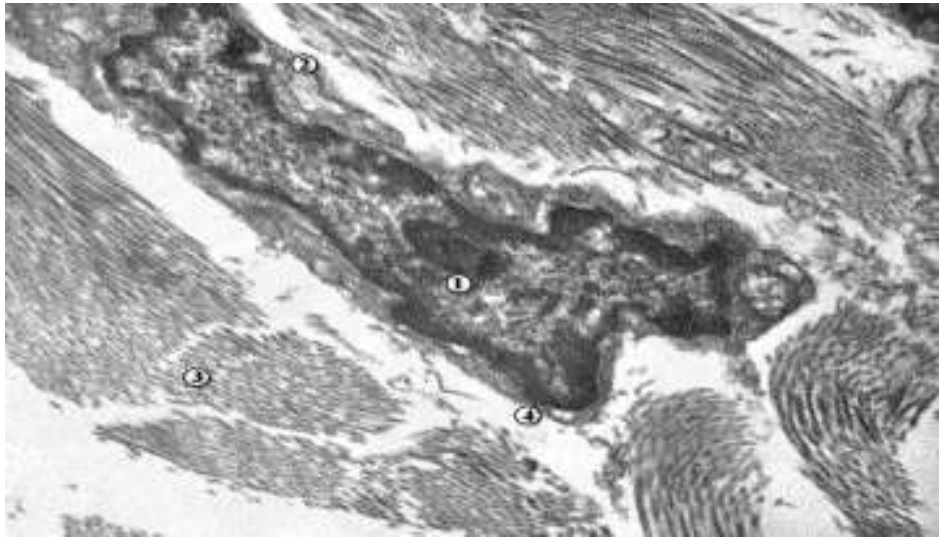

Рис. 4. Ультраструктура періодонта щура через два тижні при застосуванні опіоїду. Мікрофотографія. 3б. х15000. Ядро (1) та ичитоплазма (2) фіброцита, пучок колагенових волокон (3), електронносвітлий аморфний компонент (4). 
Проведені електронномікроскопічні дослідження слиз ової оболонки ясен тварин експериментальної групи через два тижні при застосуванні опіоїду встановили, що для мікроциркуляторного русла ясен характерні реактивні зміни. Кровоносні капіляри у цей термін досліду мають кровонаповнені просвіти. Цитоплазма ендотеліоцитів включає набряклі неширокі ділянки, у яких багато піноцитозних пухирців, кавеол, наявні вакуолі. У біля ядерній частині цитоплазми органел небагато, частина їх деструктивно змінена. Короткі канальці ендоплазматичної сітки розширені, мітохондрії з електронносвітлим матриксом, ядра виглядають збільшеними за площею, в них переважає еухроматин.

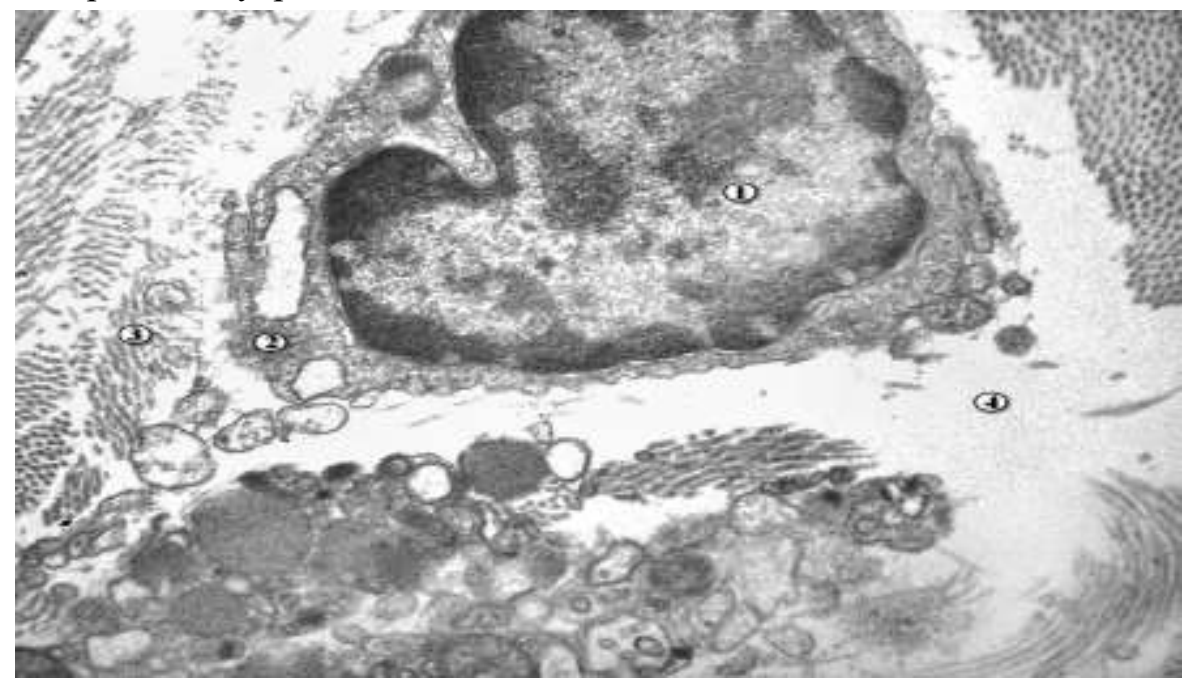

Рис. 5. Ультраструктура періодонта через два тижні при застосуванні опіоїду.

Мікрофотографія. 3б. х15000. Ядро (1) та иитоплазма (2) фіброчита, пучок колагенових волокон (3), набрякла сполучна тканина (4), фрагмент базофіла (5).

Базальна мембрана хвиляста, місцями нечітко контурована. Відмічається периваскулярний набряк, у пухкій сполучній тканині адвентиції збільшується вміст аморфного компоненту (рис. 6).



Рис. 6. Ультраструктура кровоносного капіляра власної пластинки слизової оболонки ясен щура через два тижні при застосуванні опіоїду. Мікрофотографія. 3б. х12000. Просвіт з еритроцитами

(1), цитоплазма ендотеліоцита (2), базальна мембрана (3), периваскулярний простір (4).

Субмікроскопічні зміни венул проявляються кровонаповненням просвітів, набряком цитоплазми ендотеліоцитів, деструкцією в ній органел. Окремі ендотеліоцити випинають у просвіт, мають осміофільні ядра, нерівномірний перинуклеарний простір, а в цитоплазмі різних розмірів вакуолі та електроннощільні включення. Базальна мембрана потовщена, погано контурується, периваскулярні простори збільшені (рис. 7). 


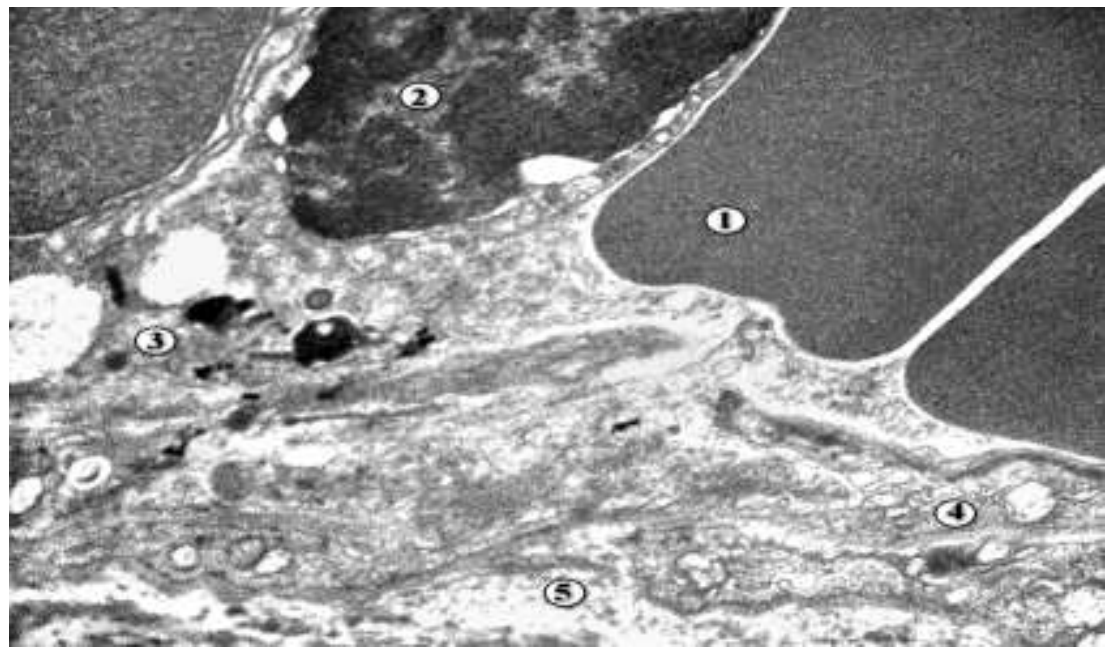

Рис. 7. Ультраструктура венули власної пластинки слизової оболонки ясен щура через два тижні при застосуванні опіӧ̈у. Мікрофотографія. Зб. х12000.

Широкий просвіт з еритроцитами (1), ядро (2) і иитоплазма (3) ендотеліочита, базальна мембрана (4), периваскулярний простір (5).

Висновки. Проведені електронномікроскопічні дослідження встановили, що на ранніх термінах опіоїдного впливу виникають незначні структурні зміни в тканинах пародонта. Короткотривала дія опіоїдного аналгетика в малих дозах призводить до реорганізації епітеліоцитів у всіх відділах епітеліальної пластинки, структурних змін в міжклітинній речовині сполучної тканини періодонта, а також реактивних змін у ланках гемомікроциркуляторного русла.

\section{ЛІТЕРАТУРА}

1. Kuzenko EV Morphological changes in periodontal tissues during inflammation / EV Kuzenko, AM Romanyuk, LI. Karpenko // Ukrainian morphological almanac. 2013; 11(2): 58-60.

2. Nazir MA. Prevalence of periodontal disease, its association with systemic diseases and prevention. / MA Nazir // In J Health Sci (Qassim). 2017; 11(2):72-80. PMID: 28539867

3. Gurav AN. The association of periodontitis and metabolic syndrome. / AN Gurav // Dent Res J (Isfahan). 2014; 11(1):1-10. PMID: 24688553

4. Saini GK Drug addiction and periodontal diseases. / GK Saini, ND Gupta, KC. Prabhat // J Indian Soc Periodontol. 2013;17:587-91. doi: 10.4103/0972-124X.119277.

5. Shekarchizadeh H. Oral health of drug abusers: A review of health effects and care. / H Shekarchizadeh, MR Khami, SZ Mohebbi, H Ekhtiari, JI.Virtanen // Iran J Public Health. 2013;42:929-40. PMCID: PMC4453891

6. Kayal RA Illicit drug abuse affects periodontal health status. / RA Kayal, WY Elias, KJ Alharthi, AK Demyati, JM Mandurah // Saudi Med J. 2014; Jul. 35 (7):724-28 [Links].

7. Rotemberg E Estado dental y periodontal de población en tratamiento por consumo de drogas: Estudio piloto. / E. Rotemberg, I Salveraglio, M. Kreiner, S Piovesan, K Smaisik, R Ormaechea, A. Varela // Rev. Odontoestomatología 2015; 17(25):34-39. [Internet]. [Acceso Octubre 2016] Disponible en: http://www.scielo.edu.uy/scielo.php scriptpid=S1688-93392015000100005

8. Fik V.B. Morphofunctional peculiarities of the periodontal tissue under conditions of simulated eight-week opioid effect / V.B. Fik, E.V. Paltov, Y.Y. Kryvko // Deutscher Wissenschaftscherold German Science Herald. 2018; 1: 14-17. DOI:10.19221/201814

9. Pang J. Chronic Opioid Use Following Surgery for Oral Cavity Cancer. / J Pang, KR Tringale, VJ Tapia, WJ Moss, ME May, T Furnish // Otolaryngol.Head Neck Surg. 2017; Apr.26, 143(12): 1187-94. doi: 10.1001/jamaoto.2017.0582

10. Queiroz-Junior CM Endogenous opioids regulate alveolar bone loss in a periodontal disease model. / CM QueirozJunior, KL Maltos, DF Pacheco, TA Silva, JD Albergaria, CM Pacheco CM // Life Sci 2013; 93:471-477

11. Paltov, YV, Fik, VB, Vilchova, IV, Onisco, RM, Fitkalo, OS., Kryvko Y.Ya (2013) Ukraine. Patent No. 76565. Kyiv: Ukrainian Institute of Intellectual Property (Ukrpatent).

12. Glauert A.M. (1975). Fixation, Dehydration and Embedding of Biological Specimens. In: Practical methods in electron microscpi. North-Hollond: American Elsevier. 